\title{
Proof of Corruption Case Based on Indonesian Audit Board Result
}

\author{
Simon Nahak, Dessy Lina Oktaviani Suendra, Kade Richa Mulyawati \\ Faculty of Law \\ Universitas Warmadewa \\ Denpasar-Bali, Indonesia \\ dessylina17@gmail.com
}

\begin{abstract}
There are some ways to prove the corruption case in Indonesia, one of which is by calculating the state financial loss. Supreme Audit Board (BPK) is one of state agencies that has the authority to conduct audit to the financial state. This study aims to analyze the substance of criminal law, particularly the conflict of norm with regards to the validity of the audit result as evidence in the process of the criminal justice system. The method used in this paper is the method of juridical-normative using historical and constitutional approach. The findings showed that the results of BPK have the legal power to prove every person and/or legal entity that commits corruption guilty. If other agencies publish the audit results, there exists a conflict of norm.
\end{abstract}

Keywords-audit result; supreme audit board; proof; corruption

\section{INTRODUCTION}

Anti-corruption is a common problem and the rule of law issues faced by countries in the world, it is related to the rise and fall of nation and ethnic honor [1]. Corruptor cases in the world in general involved three interrelated partiesbureaucrats, politicians, and businessmen. The involvement of this three is based on correlation that politicians generally require funds in electoral process and funding is generally carried out by entrepreneurs who have economic interest in it. As a return of favor politicians will make some rules for bureaucrats in order to allocate state budget for economic interest of the businessmen who desires procurement projects of government goods and services. While the corruption case in Indonesia involves not only three, but also the fourth-the judiciary [2].

After the declaration of the Indonesian independence in 1945 and the ousting of the old bureaucracy, the country managed to get rid of the corruption in the public sector of the economy for a short period of time. But, with the beginning of nationalization and the privatization of the Dutch property, the new state bureaucracy quickly adopted the habit of accepting profitable proposals only from those who paid the most to the official. The state officials, under whose control the big companies had been brought, considered those companies as a means of getting their own benefits, and thus, were taking and giving bribes avidly [3].
To eradicate the structured corruption case, the Indonesian government has various policies to anticipate it. One of them by holding a financial audit by the State Audit Board. The result of Audit as a very strong letter proof to prove the mistake of every person or legal entity who committed corruption is stated by the BPK as the affirmation of the Circular Letter of the Supreme Court of the Republic of Indonesia Number 4 of 2016 determines the State Financial Losses can only be declared by the Examining Board Finance. So other bodies are not authorized to declare it.

Based on these provisions, other bodies or institutions referred to as Financial and Development Supervisory Board (BPKP) are the non-ministerial government institutions in Indonesia that carry out governmental duties in the field of financial and development supervision in the form of Audit, Consultation, Assistance, Evaluation, eradication of Corruption, Collusion and Nepotism (KKN) as well as education and training of field supervision State finance is not authorized because the BPKP is formed only under Presidential Regulation which is hierarchically still under BPK.

The Audit Result of the BPK should be a valid evidence but in the practice of the Corruption Court of Corruption precisely, the result of the Audit used is the Financial and Development Supervisory Board abbreviated by BPKP so that this paper looks at the formulation of penalty/substance of criminal law in Conflict of Norm in terms of the validity of the Audit Result as evidence in the process of the Criminal Justice System therefore in the penal system should be formulated to regulate the legal aspects of legal proof so that there is no continuous debate between law enforcement officers with the inventors of Justice and Legal Certainty through Court of Corruption.

Based on the above background then formulated legal issues (legal issue) as follows:

- How is the Position and Authority of the BPK against Corruption Crime Proof Based on the Criminal Justice System in Indonesia?

- What is the legal power of Proof of the Result of Audit of the State Financial Losses by the State Audit Board in the Indonesian Criminal Justice System? 


\section{METHOD}

The method used in this paper is the method of juridicalnormative. The choice of juridical-normative method of writing is used to observe the legal norms conflicts in this description because of a conflict of authority between the BPK regulated by the 1945 Constitution of the State of the Republic of Indonesia, the Law on the Financial Audit Board, the Circular Letter of the Supreme Court with The authority of the Supervisory Board of the KPK that exercises its authority is only based on the Regulation of the President of the Republic of Indonesia.

\section{RESULT AND DISCUSSION}

\section{A. The position of the BPK against Corruption Crime Proof Based on the Criminal Justice System in Indonesia}

1) The position of the BPK in the Indonesian Criminal Justice System

The institutional structure in the state system of the State of the Republic of Indonesia has undergone significant changes since the amendment of the 1945 Constitution of the State of the Republic of Indonesia which in principle became the concept of development of a democratic government with equal and equal checks and balances between the legislative powers implemented by the Consultative Assembly The People, the People's Representative Council, the Regional Representative Council, Executive Powers, shall be exercised by the President and Vice President, the Judicial Power, exercised by the Supreme Court and the Constitutional Court, and the Examinative Power exercised by the State Audit Board. The description indicates that the existence of the BPK is one of the independent and independent State institutions, regardless of the influence and power of the government, but neither does it stand above the government. The position of the BPK is the only External Audit Board of the Government. Under the constitutional order, Moh. Kusnardi and Bintang R. Saragih was quoted by Titik Triwulan Tutik, wrote that in its position the BPK has 3 (three) functions, among others:

- Operative functions, namely; conduct examination, supervision, and research on the control and management of state finances;

- The function of the Judiciary, namely; to make demands of treasury and compensation claims against treasurers and Civil Servants not treasurers who, because of their unlawful conduct or neglect of their obligations, incur major losses to the State;

- Recommended Functions, namely; giving consideration to the government on the management of state finances [4].

The constitutional and bachelor's mandate proves that the BPK has a position in the Capital of the State and the Province and functions within the Judiciary; to make demands of treasury and compensation claims against treasurers and Civil Servants not treasurers who, because of their unlawful conduct or neglect of their obligations, incur major losses to the State. The position of the Audit Board is very important so that other bodies are not authorized to issue Audit Result on State
Financial lost. If other bodies publish audit results will occur conflict of legal norms, so analyzed with the Theory of Legal Certainty. According Sudikno Mertukusumo legal certainty is a guarantee that the law must be run in a good way [5].

2) Duties and authorities of the State Audit Board in the Criminal Justice System of Corruption

In the case of the result of the Audit as evidence in the Trial of the Corruption Criminal Court Article 8 paragraph (3) determines: "... if the report finds the Criminal element of the State Audit Board of such matter to the authorized entity in accordance with the provisions of the law - invitation no later than 1 (one) month since. Article 10 Paragraph (1) of the State Audit Board "and/or stipulate the amount of the State's losses resulting from acts against both committed and committed by the Treasurer, State-Owned Enterprise/State-Owned Enterprise and state financial management institution". Paragraph (2) The assessment of financial losses of the State and/or the provision of a competent authority for the purposes of paragraph (1) shall be stipulated by the decision of the State Audit Board. Based on the duties and authorities of the BPK, strictly speaking the audit result issued by the BPK is a valid legal document to prove that there is a real loss of the State to every actor of corruption committed by both individuals and legal entities.

The legal theory used to analyze this discussion is the theory of authority according to According to Philip M. Hadjon said that:

"Every governmental act is required to rely on legitimate authority. The authority is attributed through three sources, namely attribution, delegation, and mandate. The authority of attribution is usually outlined through the division of state power by the constitution, while the authority of the delegate and the mandate is the authority derived from "devolution" [6].

\section{B. Legal Strength of Proof of Result of State Financial Losses Audit by State Audit Board on Criminal Actors in Criminal Justice System in Indonesia}

Audit Result obtained by Audit Board has the legal power to prove every person and/or legal entity that is proven to commit a criminal act of corruption. Accountability basically provides a very important role in creating a good governance activity as a part of improving public confidence in government performance. The conception of accountability can be seen that government officials are not only accountable to higher authorities in the institutional chain of command but also accountable to the general public, non-governmental organizations, mass media and many other stakeholders [7].

M. Syukri Akub provides expert information in the Pretrial case of the suspect's appointment to designate "a person is designated as a suspect before the Decision of Constitutional Court (MK) no. 21/PUU-XII/2014 is based only on preliminary evidence as a criminal offender (Article 1 point 14 of the Criminal Procedure Code), that in the Constitutional Court's decision there are several phrases namely initial evidence and sufficient initial evidence, through the decision of the Constitutional Court is interpreted that in determining a person as a suspect must meet at least two valid evidences. Sufficient initial evidence of intent is as specified in Article 184 
paragraph (1) of the Code of Criminal Procedure Law determines: the valid evidence is; Statement of witnesses, expert statements, letters, instructions and explanations of the accused" [8]. The legal theory of evidence used to prove the description is the theory of negative proof by law is:

- To blame a defendant requires a minimum of proof established in the Act;

- Nevertheless, even if the evidence is stacked above the minimum specified in the law, if the judge is not convinced of the defendant's error, he shall not condemn and punish the defendant [9].

Based on the above description of the article on the state derived from the evidence of expert information (article 184 of the Criminal Procedure Code) has never been accompanied by reports of state losses issued by the BPK. The result of audit as a very strong letter proof to prove the mistake of any person/legal entity that commits a criminal act of corruption can only be declared by BPK as confirmed in Circular Letter of Supreme Court of the Republic of Indonesia Number 4 Year 2016 which determines the state financial loss can only be stated by BPK. It is also affirmed in Article 10 Paragraph (1) of Law Number 15 Year 2006 concerning the Supreme Audit Board which states: BPK assesses and/or determines the amount of state losses caused by unlawful acts either intentionally or negligently committed by the treasurer, manager BUMN/BUMD, and other institutions or bodies that organize state financial management.

However, in fact, in the implementation of the criminal justice process, the results of the audit from the Financial and Development Supervisory Board (BPKP) are more used as evidence in the criminal act of corruption. BPKP is an Indonesian non-state government institution that performs governmental tasks in the field of financial and development supervision in the form of Audit, Consultation, Assistance, Evaluation, eradication of corruption, collusion and nepotism as well as education and training on state financial supervision. It is mentioned in Article 3 letter $b$ of the Presidential Regulation of the Republic of Indonesia Number 192 of 2014 concerning the Financial and Development Supervisory Board. Based on the regulation, it can be seen that BPKP is hierarchically still under the BPK because it is only regulated in the Presidential Regulation while the BPK is regulated in the law. The legal argument that can support this is hierarchy of the formulation of Legislation in Article 7 paragraph (1) RI Law no. 12 In 2011, specify: the type and hierarchy of legislation consists of: Constitution of the Republic of Indonesia Year 1945, the Decree of the Assembly, Law/Government Regulation in Lieu of Law, the Presidential Decree, Regulations Provincial and Local Regulations Country Town. Based on this, then the audit result from BPKP is more appropriate to be used as evidence in corruption crime. The author illustrates that the Audit Result of the BPK is a legal proof in the criminal act of corruption because it is like a murder case, it would not be possible to say there was a criminal murder case if no victims died. So, if there is no audit result of state losses, then the action cannot be said to be a criminal act of corruption.
The theory used in addition to the theory of negative proof according to the Law also used the theory of Combined Penal System according to the Theory of Combined, states that the punishment also intends to improve people who have committed evil, called the Theory of fixing (verbeteringstheorie), in addition there is also an opinion that says that the basis of the punishment is retaliation but the other intent (prevention, fear, maintaining the order of common life, improving the one who has acted, should not be ignored, this theory is called Combined Theory "[10]. The combined theory of Vos described in Bambang Poernomo, explains that in the combined theory there are 3 (three) streams, namely:

- Combined theories that emphasize revenge, but with the intention of the criminal nature of retaliation to protect the rule of law. Zeven Bergen states in this respect the nature of the criminal is retaliation, but for the purpose of protecting lawful order, to respect to law and government. Thus in essence the penalty is only a "Ultimum Remedium" (in the end which can heal that a last resort may be used if there is no other way);

- Combined theory that emphasizes the protection of public order. This theory is embraced by Simons who uses the notion that public prevention lies in the horror of crime, repair and destruction, and then in absolute terms the penalty must be in accordance with the legal consciousness of the community members;

- Combined theory that emphasizes equality of retaliation and protection of public interest. This follower is De Pinto, whom Vos explained that because in general a criminal must satisfy the society the criminal law must be structured in such a way as a fair criminal law, with the idea of retaliation that cannot be neglected negatively or positively [11].

The author agrees with the combined theory because the nature of criminal law is ultimum remedium, the joint theory aims to protect the public that is to protect public order and the criminal must be adjusted with the legal awareness of community members, so that the perpetrators of Corruption should be improved by socialization of criminal sanctions in applicable provision.

\section{CONCLUSION}

The position and authority of the Supreme Audit Agency against Corruption Crime Proofing under the Criminal Justice System in Indonesia is the position and authority of a very important institution. The State Financial Losses can only be announced and declared by the State Audit Board. So that other bodies are not authorized to issue Audit Result on State Financial Loss, if other bodies publish audit results will occur conflict of legal norms.

The BPK has the legal power to prove every person and/or legal entity proven to commit corruption. This is confirmed in Circular Letter of Supreme Court of the Republic of Indonesia Number 4 Year 2016 which determines the state financial loss can only be stated by BPK. It is also affirmed in Article 10 Paragraph (1) of Law Number 15 Year 2006 concerning the Supreme Audit Board which states: BPK assesses and/or 
determines the amount of state losses caused by unlawful acts either intentionally or negligently committed by the treasurer, manager State-Owned Enterprise (SOEs) or Regional-Owned Enterprises (ROEs), and other institutions or bodies that organize state financial management.

\section{ACKNOWLEDGEMENT}

The author would like to thank all the parties who have helped and contributed in the writing of this article, both those who contribute in the form of funding and critical ideas. Hopefully this paper can be useful theoretically and practically for the addition and development of knowledge, especially in the field of legal science.

\section{REFERENCES}

[1] M. Sun, Research on the Inspection and Optimization of AntiCorruption Criminal Rule of Law in Contemporary China, Atlantis Press, 2nd International Conference on Education, Social Science, Management and Sports (ICESSMS 2016), 2016, p.153-157.

[2] Rozmita D. Y. R, The Detection of Corruption and The Role of Accountant in Achieving Good Public Governance, Atlantis Press, 1st
Global Conference on Business, Management and Entreupreuneurship (GCBME-16), 2016, p.1-7.

[3] A. Blenchenko, History of an Anti-Corruption Struggle Based on the Experience of the Republic of Indonesia, Atlantis Press, International Conference on Contemporary Education, Social Sciences and Humanities (ICCESSH 2017), 2017, p. 1063-1069.

[4] T. T. Tutik, Hukum Tata Usaha Negara dan Hukum Acara Peradilan Tata Usaha Negara Indonesia, Kencana Predana Media Group, Jakarta, 2011.

[5] S. Mertokusumo, Mengenai Hukum, Sebuah Pengantar, Liberty, Yogyakarta, 1999.

[6] P. M. Hadjon, Fungsi Normatif Hukum Administrasi dalam Mewujudkan Pemerintahan yang Bersih, Pidato Penerimaan Jabatan Guru Besar dalam Ilmu Hukum pada Fakultas Hukum Universitas Airlangga, Surabaya, 1994.

[7] Khotami, The Concept of Accountability in Good Governance, Atlantis Press, The Concept of Accountability in Good Governance (ICODAG 2017), 2017, p.30-33.

[8] Syukri, A. M., Keteranggan Ahli Pidana dalam Putusan Pengadilan Negeri Denpasar No. 21/Pid.Pra/2017/PN.Dps, 2017.

[9] Soebekti, R., Hukum Pembuktian, Penerbit Pradnya Paramita, Jakarta, 1975.

[10] Soesilo R., Kitab Undang-Undang Hukum Pidana (KUHP) Serta Komentar-Komnetarnya Lengkap Pasal demi Pasal, Bogor: Politeia. 1996.

[11] Bambang P. H., Asas-Asas Hukum Pidana, Jakarta: Chalia Indonesia. 1985. 